\title{
What are the factors responsible for increase in SARS-CoV-2/Covid-19 Pandemic related cases and death in India in 2021? How does environmental, host \& agent factors of epidemiological triad do influence \& can be utilised to manage ongoing pandemic cases and deaths?
}

\author{
Dr Piyush Kumar,M.B.B.S., E.M.O.C., ${ }^{1}$ \\ ${ }^{1}$ Affiliation not available
}

May 10, 2021

Title: - What are the factors responsible for increase in SARS-CoV-2/Covid-19 Pandemic related cases and death in India in 2021? How does environmental, host \& agent factors of epidemiological triad do influence \& can be utilised to manage ongoing pandemic cases and deaths?

Author: - Dr Piyush Kumar, M.B.B.S. - Sri Krishna Medical College, EMOC-PMCH General Medical Officer- Bihar Health Services- Government of Bihar, India.

\begin{abstract}
Background: - This time last year in 2020 India was under lockdown phase, many theories about India's surprisingly low rates of Sars-CoV-2 infection included variety of factors including hot weather, natural immunity, heard immunity, robust health system, highly qualified doctors and the country's high proportion of young people; some also attributed it to the country's harsh lockdown. India was doing so well that in megacities like Mumbai and Delhi, officials had begun dismantling temporary COVID-19 facilities. Comparing it to current scenario in April 2021, cases and deaths are soaring. The shortage of beds and space is so acute that people are dying in car parks and other places while waiting to be admitted in hospitals. Daily rates are currently over 300,000, the world's highest-ever daily infection rate.11https://www.gavi.org/vaccineswork/whyindias-covid-19-pandemic-skyrocketing
\end{abstract}

The SARS-CoV-2/ Covid -19 pandemic is still going on and globally as well as in India particularly healthcare system is overstressed with this new burden added with previous $\mathrm{NCD}$ (non communicable diseases) \& $\mathrm{CD}$ (communicable diseases). The First human case of this global pandemic was reported from Wuhan city of China in December 2019.22https://apps.who.int/iris/bitstream/handle/10665/332197/WHO-2019-nCoVFAQ-Virus_origin-2020.1-eng.pdf The first case of covid-19 in India was found in January 2020. Today India is having more than 3 lakh cases per day and thousands of deaths daily due to this pandemic. The situation is very worse as compared to previous year and is worsening day by day due to several factors.

Objective: - The main objective of this study is to illustrate the key features of Covid -19 virus, host human beings factors, irresponsibility's and environmental factors responsible for continuation and recurrence of this pandemic as well as worsening of pandemic day by day. Setting and design: - Different aspects of Covid -19 structural variations, mutations, host factors, environmental factors (internal \& external) and its effect will be analysed. Brief details about epidemiological triad will be outlined.Methodology : - The explanation will be given to title through analysis of several factors responsible for increase in cases. The cause of perpetuation of Covid -19 can be understood by the way of infections and other related factors. 
Result : - Several factors are responsible for the continuation and worsening of pandemic situation in India of the pandemic. Of great concern today is a new 'double mutant' B1617 variant, identified in India last year, that is spreading across the country as well as triple variants discovered recently and studies are going on to know more. Although scientists are still investigating whether or not the variant is more deadly \& more infectious, it does contain the L452R mutation that affects the virus' spike protein. This protein is very significant because through this the virus hooks on to our cells receptor. Early research suggests that this mutation makes the virus more infectious. This doesn't necessarily mean that the variant will be any more deadly, but it means that more people are at risk.33https://www.gavi.org/vaccineswork/why-indiascovid-19-pandemic-skyrocketing

Conclusion : - In the epidemiological triad we have agent/host/environment. The clinical approach is based on individuals \& standard treatment guidelines-protocols and public health approach is based on population strategy to control this pandemic. Various strategies and approaches are required to prevent epidemic through assessment of important parameters and indicators (see figure 1) to control the ongoing disaster and hazards of pandemic

Keywords: - SARS-Cov-2, Covid-19, Pandemic, Strain,

Background - This time last year in 2020 India was under lockdown phase, many theories about India's astonishingly low rates of COVID 19 infection included variety of factors including hot weather, natural immunity, heard immunity, robust health system, highly qualified doctors and the country's high proportion of young people; some also attributed it to the country's harsh lockdown. India was doing so well that in megacities like Mumbai and Delhi, officials had begun dismantling temporary COVID-19 facilities. Comparing it to current scenario in April 2021, cases and deaths are soaring, leaving hospitals running out of oxygen \& beds with other medicines and required facilities. The shortage of beds and space is so acute that people are dying in car parks and other places while waiting to be admitted in hospitals. Daily rates are currently over 300,000, the world's highest-ever daily infection rate

The SARS-CoV-2/ Covid -19 pandemic is still going on and globally healthcare system is overstressed with this new burden added with previous NCD \& CD in existence. The First human case of this global pandemic was reported from Wuhan city of China in December 2019. The first case of covid-19 in India was found in January 2020. Today India is having more than 3 lakh cases per day and thousands of deaths daily due to this pandemic. The situation is very worse as compared to previous year and is worsening day by day due to several factors.

The SARS-CoV-2/ Covid -19 coronavirus belongs to a large family of coronavirus. Usually they cause respiratory infection in humans like other respiratory viruses such as rhinoviruses/ human respiratory syncytial virus/ parainfluenza viruses/ adenoviruses/influenza A \& B viruses / enteroviruses / herpes simplex viruses/ human metapneumoviruses etc.44Harrisons Principles of Internal Medicine-18th edition volume 1 If we look at the history SARS-2002/2003 - south china outbreak begin with 8096 recognised cases in 28 countries \& added to this $90 \%$ of cases occurred in china and hongkong. Now the world is moving very fast or we can say the host factors related spread have exaggerated the pandemic added with various climatic changes. That time the natural reservoir of SARS-CoV appeared to be horseshoe bat. The 2002-2003 outbreaks thought to be originated due to human contacts with infected domestic animals. The striking fact is that in 2002-2003 as well as 2019-2020-2021 most cases spread from human to human and there are multiple ways of spread particularly respiratory droplets. The 2002 outbreak ceased in 2003 but 2019 outbreak is going on and global fast movement is one of the most important factors. The super spreaders may remain symptomless while spreading the virus.

WHO (world health organisation) have notified and actually its alarming and alerting that globally new covid-19 cases are rising again or we can say alternatively that incidence rate is increasing. In the last week of March 2021 the new cases reported globally are more than 3.8 million. At the same time the number of deaths also increased consecutively for the second consecutive week. The deaths increased by $5 \%$ compared to previous week. The total number of death for above mentioned period was over 64000 new deaths. The 
more alarming fact is that all regions have reported an increase in incidence rate in last week of March 2021. If we talk about deaths then except African region all regions reported an increase in the number of deaths due to covid-19. Added to above facts still the European region with region of Americas are on the top accounting for $80 \%$ of all cumulative cases and deaths.55https://www.who.int/publications/m/item/weeklyepidemiological-update-on-covid-19-31-march-2021 There is sharp rise in south East Asia region or actually it's the largest increase on global basis that is $21 \%$ increase in deaths with continued increasing trends in the $3^{\text {rd }}$ consecutive week.

The south East Asian region is also having a huge population as well as many nations are in developing stage with stressed and overburdened health system. The health system administration and management in India is such that the topmost positions are acquired by people who are not from the medical, clinical or public health backgrounds. All the important decision is taken by these non technical persons as well as India is always having problems of corrupt practices and haphazard system failures in critical circumstances. Added to this there is lack of human resources, infrastructure, and capacity building, to cater the huge population which is growing day by day. The number of beds and medical resources are not enough and not sufficient as per international norms and this pandemic have added an extra demand on the system which is already overburdened.

Objective - The main objective of this study is to illustrate the key features of Covid -19 virus and mutations as well as strains added with host and environmental factors responsible for continuation, recurrence \& increase in number of death and cases in India. The global scenario of covid-19 pandemic see table 1- Newly reported and cumulative COVID-19 confirmed cases and deaths, by WHO Region, as of 28 March 2021source - WHO \& table-2- Overview of variants of interest (VOIs), as of 30 March 2021 - source - WHO

The whole group of coronavirus is very peculiar. They are pleomorphic, single stranded RNA viruses measuring about 100-160 nm in diameter. There are several factors responsible for the continuation of covid-19 pandemic. Broadly we can look at the epidemiological triad i.e. agent, host and environmental factors.

Setting and design - Different aspects of Covid -19 structural variations (see table 2) and its effect will be analysed. Brief details about epidemiological triad will be outlined. All the triad of epidemiology is detailed (see figure 1) to tackle the pandemic in proper way.

Agent coronavirus is having continuous variations one of the factors responsible for the ongoing covid-19 pandemic. These viruses have crown like appearance produced by club shaped projections that studs the viral envelope. The coronavirus group actually infects a wide variety of animals of different species. These are divided into three antigenic and genetic groups.

Methodology - Beside host and environmental factors the cause of perpetuation and increase in number of Covid -19 cases and deaths can be understood by the way SARS (SARS - CoV) CORONAVIRUSES is causing human infections. They fall in group 1 and 2. The old human isolates were HCoV-229E and HCoV-OC43. SARS-CoV-2 was earlier considered to be a novel group of viruses (novel coronavirus, $\mathrm{n}$ covid-19) but now they are placed in group 2 (SARS-CoV-2). The covid-19 virus has shown variations. There are variations and mutations see table- 2 which is taken into consideration added with host factors and environmental factors.

Result- Several factors are responsible for the continuation of the pandemic. Of great concern today is a new 'double mutant' B1617 variant, identified in India last year, that is spreading across the country as well as triple variants discovered recently and studies are going on to know more. Although scientists are still investigating whether or not the variant is more deadly \& more infectious, it does contain the L452R mutation that affects the virus' spike protein. This protein is very significant because through this the virus hooks on to our cells receptor. Early research suggests that this mutation makes the virus more infectious. This doesn't necessarily mean that the variant will be any more deadly, but it means that more people are at risk. 


\section{Following group of factors are responsible for increase in cases and deaths in India:}

The agents factors mainly responsible are different strains variations, mutations (double/triple) see table 2. Different strains vary in virulence, infectivity, pathogenecity, reproduction resulting in different case fatality, mortality \& morbidity rates. The prevalence rate and incidence rate is also dependent on above factors. The TCID 50 and cycle threshold values are equally important to assess the severity of infection. The attack rate, secondary attack rate and reproduction number should be taken into account while doing assessment of agent factors. Without having sound knowledge of above mentioned agent factors it's just impossible to effectively control this pandemic.

The pathogenesis of the strains causing common cold e.g. HCoV-229E and HCoV-OC43 says that they infect ciliated epithelial cells in the nasopharynx via the aminopeptidase 1 receptor (group 1) or a sialic acid receptor. Viral replication leads to a cascade of events manifested externally as common cold symptoms similar to other virus group called rhinoviruses. 11Harrisons principles of internal medicine https://www.who.int/emergencies/diseases/novel-coronavirus-2019/advice-for-public

SARS-CoV infects the respiratory tract via ACE 2 receptors. The systemic illness is manifested more or less depending upon immune status as well as associated morbidity conditions. The systemic manifestations include variety of signs and symptoms and sometime it's symptomless. The study of pulmonary pathology will reveal more findings in coming days. One key finding is that earlier 2002-2003 outbreaks have many similarities with ncovid-19. The disease is milder in children and ARDS is also found in ncovid-19 severe cases. Besides this symptoms of common cold etc are very much similar. The incubation period is 1-14 days range. In earlier cases 2002-2003 laboratory findings have shown in SARS lymphopenia present in approx $50 \%$ cases resulting in decreased immunity. Mostly T cells CD4+ (helper t cells) were affected and also $\mathrm{CD} 8+\mathrm{T}$ cell as well as natural killer to some extent.

The detailed information about ncovid-19 is yet to be finalised as several strains have been found and the trends shows that these variations will keep going. The global market has several accredited vaccines duly recognised by World Health Organisation. The final analysis and results can be declared only after a large population of world get vaccinated and with the development of herd immunity the predictions can be clearer.

The main problem in understanding morphology and other important determinants to know more about this virus is that it's difficult to cultivate it in vitro added with continuous variations. We can grow some strains in human tracheal organ cultures but quite difficult to grow in tissue culture. SARS-CoV is exceptional as it can be grown in African green monkey kidney (Vero -E6) cells facilitating to know more about this virus.

Generally human coronavirus infections present globally. Seroprevalence studies have demonstrated this fact. The seasonal trends in India shows that infection is more common in late fall, summer, and early spring times March to September). The huge population needs several other modifications which are discussed in conclusion which are responsible for spread and increase in number of death in India recently.

Host factors - As we are aware of the fact that corona viruses infects a variety of hosts we must have a proper plan to avoid contacts with other animals etc known to be reservoir of covid-19. The human beings are infected from covid-19 through droplets and many other modes. Here the infection can be dealt through clinical approach, public health or preventive approach. Best is a combination of both approaches. See figure 1. The public health approach as well as clinical approach should work in co-ordination to achieve the desired results. The governance should have a clear data regarding health workforce, finance, available no. of beds and several other parameters illustrated in figure 1 to act in effective way to provide healthcare to persons who need it most.

Very large population having freedom to move, poor governance, added with poor health management and future vision as well as limited health resources \& infrastructure are important factors related to increase in number of cases and deaths in India.

There may be different modes of transmission for SARS-CoV-2, including contact, droplet, airborne, fomite, fecal-oral, blood borne, mother-to-child, and animal-to-human transmis- 
sion. Infection with SARS-CoV-2 primarily causes respiratory illness ranging from mild disease to severe disease and death, and some people infected with the virus never develop symptoms11https://www.who.int/news-room/commentaries/detail/transmission-of-sars-cov-2-implicationsfor-infection-prevention-precautions. Looking at huge number of cases and lack of well established meritorious scientific research it's very difficult for India to control the pandemic. Like previous year if the pandemic subsides on itself then India should develop a proper strategy with future vision.

Environmental factors - The environmental factors of key importance are modifications and sanitary measures required to halt the progress of pandemic. Water, sanitation, food and air quality are vital elements in the transmission of communicable diseases and in the spread of diseases prone to cause epidemics.

A number of environmental factors influencing the spread of SARS-CoV-2 diseases are prone to cause epidemics. The most important of these are:

- water supply

- sanitation facilities

- food

- Climate. Climate can affect disease transmission in a variety of ways. The distribution and population size of disease vectors can be heavily affected by local climate. Flooding after heavy rains can result in sewage overflow and widespread water contamination. In addition, there is some evidence to suggest that pathogens can be spread from one region to another along air streams or by wind22https://www.who.int/teams/environment-climate-change-andhealth/emergencies/disease-outbreaks/.In India there is improper living condition in reference to above mentioned conditions resulting in surge of cases and deaths.

Conclusion - In the epidemiological triad we have agent/host/environment. For controlling this pandemic of covid-19 we have to apply clinical \& public health approach. Our mind should be clear to have a keen and deep view of epidemiological triad. The epidemiological triad (concept of causation) consist of agent (causative factor), host (those who get infected from agent) and the surroundings (ecology, environment etc.).

What we can do regarding agent; - We have to assess following and act accordingly

- Various Strains \& mutations

- Virulence of strains

- Infectivity of strains

- Pathogenecity of strains

- attack rate of strains

- secondary attack rate of strains

- reproduction number of strains

- Prevalence \& Incidence rates of strains

- TCID-50 assay \& cycle threshold of strains infecting

- Monitoring \& evaluation of strains

What we can do regarding Host and related parameters; - We have to assess following and act accordingly

Preventive Approach/Method /Risk factors

- Primordial/Primary/secondary/tertiary PREVENTION

- HALE/QALY/DALY estimation

- Hospital Admission rate/Bed occupancy ratio estimates

- Lockdown imposition if required

- Social Medicine and social awareness

- Physical/Mental /Psycho-Social health care

- Age/Sex/Genetic/Ethnicity considerations 
- social/economic/risk groups or target groups/vulnerability assessment

- Curative or clinical Approach/Methods for symptomatic cases with defined treatment protocols and guidelines

- Clinical Methods/ spectrum of disease/Iceberg of disease assessment

- Accessible/Affordable/Available/Equity in healthcare delivery system

- Women/children/aged/co-morbidity/Special \& vulnerable safety

- Triage \& Health Index assessment

- Healthcare Delivery status

- Doctor/Nurse-Population Ratio

- Screening- test/track/treat/Isolate

- Early diagnosis \& treatment with appropriate guidelines \& treatment protocols

- specific protection-immunisation status

- Herd Immunity assessment, continue surveillance \& monitoring of new-suspected cases to prevent further disaster

- Develop strategy for controlling virulent strain spread

- Capacity building among health staff

- Case Fatality rate

- Aim to reduce Prevalence \& Incidence Other will get reduced with reduced economic loss

- Control \& eliminate/eradicate

- surveillance / monitoring/ evaluation for long term to prevent recurrence

- Mortality

- Morbidity

- Crude Death Rate

- Age specific Death Rate

- Structure of Variants of interest

What we can do regarding environment and related parameters; - We have to assess following and act accordingly

- Sanitary Awareness through various communication channels

- Disease control techniques to be adapted in daily lifestyle

- Health promotion/Social /Community/Family/Society/Media/IEC/BCC awareness

- Governance to implement protective strategy

- individual \& mass education

- sustained behaviour change \& positive deviance development

- environmental modifications to prevent spread

- Ecology assessment to prevent spread

- Living conditions modification to prevent spread

- Internal (immunization)/External environment (sanitary measures) modification to prevent spread

- Lifestyle Modification

- Population \& high risk strategy to control pandemic

- fresh air/clean environment

- Avoid these 3Cs: spaces that are $c$ losed $c$ rowded or involve $c$ lose contact.

- Outbreaks have been reported in public places with gatherings such as restaurants, choir practices, fitness classes, nightclubs, offices and places of worship where people have gathered, often in crowded indoor settings where they talk loudly, shout, breathe heavily or sing.

- The risks of getting COVID-19 are higher in crowded and inadequately ventilated spaces where infected people spend long periods of time together in close proximity. These environments are where the virus appears to spread by respiratory droplets or aerosols more efficiently, so taking precautions is even more important.

- Meet people outside. Outdoor gatherings are safer than indoor ones, particularly if indoor spaces are small and without outdoor air coming in. 
- Avoid crowded or indoor settings but if you can't, then take precautions:

- Open a window. Increase the amount of 'natural ventilation' when indoors.

- Wear a mask.11https://www.who.int/emergencies/diseases/novel-coronavirus-2019/advice-forpublicFigure-1-factors to be checked for making covid-19 control plan.Table 1 - Newly reported and cumulative COVID-19 confirmed cases and deaths, by WHO Region, as of 28 March 2021- source - WHO

\begin{tabular}{|c|c|c|c|c|c|c|}
\hline WHO Region & $\begin{array}{l}\text { New cases in } \\
\text { last } 7 \text { days (\%) }\end{array}$ & $\begin{array}{l}\text { Change in new } \\
\text { cases in last } 7 \\
\text { days } *\end{array}$ & $\begin{array}{l}\text { Cumulative } \\
\text { cases (\%) }\end{array}$ & $\begin{array}{l}\text { New deaths in } \\
\text { last } 7 \text { days }(\%)\end{array}$ & $\begin{array}{l}\text { Change in new } \\
\text { deaths in last } \\
7 \text { days } *\end{array}$ & $\begin{array}{l}\text { Cumulative } \\
\text { deaths }(\%)\end{array}$ \\
\hline Americas & $\begin{array}{l}1306017 \\
(34 \%)\end{array}$ & $11 \%$ & $\begin{array}{l}55243776 \\
(44 \%)\end{array}$ & $32176(50 \%)$ & $4 \%$ & $\begin{array}{l}1331419 \\
(48 \%)\end{array}$ \\
\hline Europe & $\begin{array}{l}1641672 \\
(43 \%)\end{array}$ & $11 \%$ & $\begin{array}{l}44191579 \\
(35 \%)\end{array}$ & $23778(37 \%)$ & $7 \%$ & $954829(34 \%)$ \\
\hline $\begin{array}{l}\text { South-East } \\
\text { Asia }\end{array}$ & $437060(11 \%)$ & $46 \%$ & $\begin{array}{l}14619886 \\
(12 \%)\end{array}$ & $2947(5 \%)$ & $21 \%$ & $217737(8 \%)$ \\
\hline $\begin{array}{l}\text { Eastern } \\
\text { Mediterranean }\end{array}$ & $270884(7 \%)$ & $3 \%$ & $7395085(6 \%)$ & $3428(5 \%)$ & $5 \%$ & $156891(6 \%)$ \\
\hline Africa & $62286(2 \%)$ & $22 \%$ & $3061438(2 \%)$ & $1340(2 \%)$ & $-6 \%$ & $77446(3 \%)$ \\
\hline $\begin{array}{l}\text { Western } \\
\text { Pacific }\end{array}$ & $84395(2 \%)$ & $32 \%$ & $1859933(1 \%)$ & $518(1 \%)$ & $7 \%$ & $31361(1 \%)$ \\
\hline Global & $\begin{array}{l}3802314 \\
(100 \%)\end{array}$ & $14 \%$ & $\begin{array}{l}126372442 \\
(100 \%)\end{array}$ & $64187(100 \%)$ & $5 \%$ & $\begin{array}{l}2769696 \\
(100 \%)\end{array}$ \\
\hline
\end{tabular}

Table 2: Overview of variants of interest (VOIs), as of 30 March 2021 - source - WHO

\begin{tabular}{|c|c|c|c|c|c|c|}
\hline $\begin{array}{l}\text { Next strain } \\
\text { clade }\end{array}$ & $20 \mathrm{C}$ & $20 \mathrm{C} / \mathrm{S} .452 \mathrm{R}$ & 20B/S.484K & $\begin{array}{l}\text { Not yet } \\
\text { assigned }\end{array}$ & $20 \mathrm{C}$ & $20 \mathrm{C}$ \\
\hline $\begin{array}{l}\text { PANGO } \\
\text { lineage }\end{array}$ & B.1.525 & B.1.427/B.1.429 & $\begin{array}{l}\text { B.1.1.28.2, } \\
\text { alias P.2 }\end{array}$ & $\begin{array}{l}\text { B.1.1.28.3 } \\
\text { alias P.3 }\end{array}$ & $\begin{array}{l}\text { B.1.526 } \\
\text { (with E484K } \\
\text { or S477N) }\end{array}$ & $\begin{array}{l}\text { B.1 } \\
\text { descendant } \\
\text { with } 9 \\
\text { mutations }\end{array}$ \\
\hline $\begin{array}{l}\text { GISAID } \\
\text { clade }\end{array}$ & G/484K.V3 & GH/452R.V1 & GR & $\begin{array}{l}\text { Not yet } \\
\text { assigned }\end{array}$ & GH & GH \\
\hline $\begin{array}{l}\text { Alternate } \\
\text { names }\end{array}$ & & CAL.20C/L452R & & $\begin{array}{l}\text { PHL- } \\
\text { B.1.1.28 }\end{array}$ & & \\
\hline $\begin{array}{l}\text { First } \\
\text { detected by }\end{array}$ & $\begin{array}{l}\text { United } \\
\text { Kingdom } \\
\text { and Nigeria }\end{array}$ & $\begin{array}{l}\text { United } \\
\text { States of } \\
\text { America }\end{array}$ & Brazil & $\begin{array}{l}\text { Philippines } \\
\text { and Japan }\end{array}$ & $\begin{array}{l}\text { United } \\
\text { States of } \\
\text { America }\end{array}$ & France \\
\hline $\begin{array}{l}\text { First } \\
\text { appearance }\end{array}$ & $\begin{array}{l}\text { December } \\
2020\end{array}$ & June 2020 & April 2020 & $\begin{array}{l}\text { February } \\
2021\end{array}$ & $\begin{array}{l}\text { November } \\
2020\end{array}$ & $\begin{array}{l}\text { January } \\
2021\end{array}$ \\
\hline
\end{tabular}




\begin{tabular}{lllllll}
\hline $\begin{array}{l}\text { Next strain } \\
\text { clade }\end{array}$ & 20C & 20C/S.452R & 20B/S.484K & $\begin{array}{l}\text { Not yet } \\
\text { assigned }\end{array}$ & 20C & 20C \\
\hline Key spike & H69-V70 & L452R; & L18F; T20N; & 141-143 & L5F; T95I; & G142 deletion; \\
mutations & deletion; Y144 & W152C; S13I; & P26S; F157L; & deletion; & D253G; & D66H; Y144V; \\
& deletion; & and D614G & E484K; & E484K; & D614G; & D215G; \\
& Q52R; E484K; & & D614G; S929I; & N501Y; and & A701V; and & V483A; \\
& Q677H; & & and V1176F & P681H & E484K or & D614G; \\
& D614G; and & & & & S477N & H655Y; \\
& F888L & & & & G669S; \\
& & & & & Q949R; and \\
\hline
\end{tabular}

Themodificationatoneoftheabovefactorswillmodifyotherfactorspositivelyornegatively.Nowwehavetokeepinmindthat

- Thenewstrainswillkeeponevolvingasit'sanaturaleventandpracticallyimpossibletochangethisfactorofmutationetc.

- Wecandoalotatthehostfactorsandlotsofguidelinesareissuedbynational/internationalorganisationsparticularlyWHO.Thein

- AttheenvironmentallevelalsowecankeepourenvironmentsafebyadaptingWASHandotherguidelinestomakeworldasaferplace

- Atlastbutnotleastglobalcoordinationisrequiredtostopthispandemicandanyfuturemutationsincreasingvirulenceofcovid19willhaveadetrimentaleffectgloballyifnotstoppednowthroughinternationalcollaborations.

- COVID-19vaccinesaregiveninIndiaforseveralmonths,butinitiallythereishesitancyduetolackofproperinformation,education

- IndianeedstowatchcarefullyfortheIndianvarianttoemergeelsewhereinothernations. Whilesomecountrieshavebannedtravelt 19were seenonoutboundflightsbetweenIndiaandCanadabetween4and14April.WhilemostplanesarenowgroundedinIndia,itı

- Indianeedstoreconstructhealthsystemhierarchytoallowpeoplehavingknowledgeofhealthsciencetotakechargeofhealthdepar technicaladministratorstodealwithdiseasesineffectiveway.

'Declarations':-Thispaperhasnotbeenpreviouslypublishedandisnotcurrentlyunderconsiderationbyanotherjournal.Thedocume Ethicsapprovaland consenttoparticipate:Notapplicable. Thisstudyhasnotinvolvedanyhumanoranimalsinrealorforexperime Consentforpublication:Notapplicable-Availabilityofdataandmaterials:Thedata\&materialssourceiswelllistedinreference

\section{-Conflicts of Interest/ Competing Interest}

There are no conflicts / competing of interest

- Funding -Self sponsored. No aid taken from individual or agency etc.

- Authors' contributions : The whole work is solely done by the Author - Dr Piyush Kumar

-Authors' Qualification \& Affiliations': M.B.B.S. - Sri Krishna Medical College, EMOC-PMCH General Medical Officer- Bihar Health Services- Government of Bihar, India.

- Acknowledgements - I am thankful to Advocate Anupamamy wife for cooperation.

- Author information: The author is currently working as general medical officer for the government of Bihar.

-Financial Support \& sponsorship : Nil

\section{REFERENCES}

https://www.gavi.org/vaccineswork/why-indias-covid-19-pandemic-skyrocketing

https://apps.who.int/iris/bitstream/handle/10665/332197/WHO-2019-nCoV-FAQ-Virus_origin-2020.1-

eng.pdf

https://www.gavi.org/vaccineswork/why-indias-covid-19-pandemic-skyrocketing

Harrisons Principles of Internal Medicine-18th edition volume 1 
https://www.who.int/publications/m/item/weekly-epidemiological-update-on-covid-19-31-march-2021 https://www.who.int/news-room/commentaries/detail/transmission-of-sars-cov-2-implications-forinfection-prevention-precautions

https://www.who.int/teams/environment-climate-change-and-health/emergencies/disease-outbreaks/ https://www.who.int/emergencies/diseases/novel-coronavirus-2019/advice-for-public 